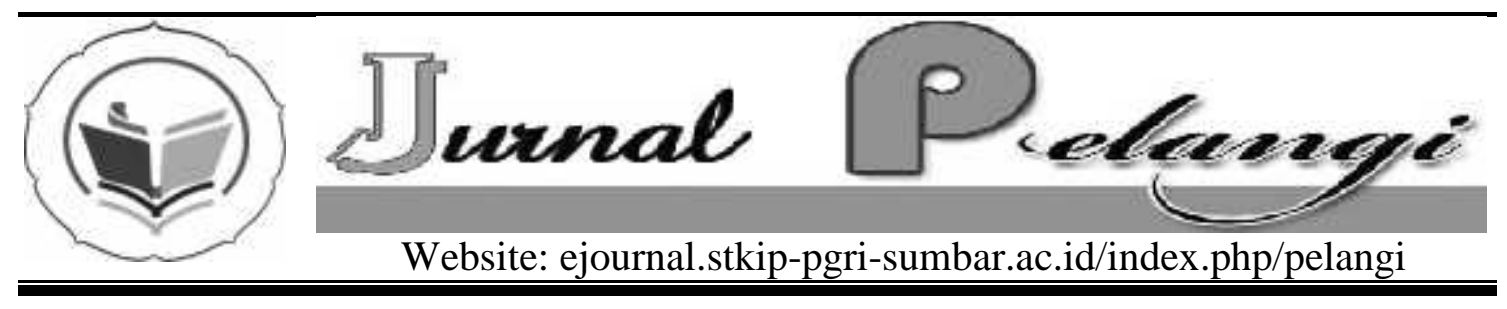

\title{
EFEKTIVITAS PENGEMBANGAN MEDIA PEMBELAJARAN BERBASIS KOMPUTER TERHADAP SIKAP MAHASISWA PADA PERKULIAHAN GEOMETRI RUANG
}

\author{
Mulia Suryani $^{1)}$, Melisa ${ }^{2)}$ \\ ${ }^{1,2)}$ Program Studi Pendidikan Matematika STKIP PGRI Sumatera Barat \\ ${ }^{1)}$ muliasuryani@gmail.com \\ ${ }^{2)}$ melisa@gmail.com
}

INFO ARTIKEL

Diterima : 02/02/2014

Disetujui : 30/05/2014

Kata Kunci:

Media Pembelajaran, Komputer,

Sikap,

Geometri Ruang

\begin{abstract}
Abstrak
Penggunaan sumber belajar yang tidak bervariasi menyebabkan mahasiswa jenuh dan bosan dalam mengikuti perkuliahan. Kejenuhan yang dialami mahasiswa menghambat mereka untuk berfikir kreatif sehingga mereka hanya berpatokan pada contoh soal dan pembahasan yang diberikan dosen. Untuk mengatasi permasalahan di atas salah satu media pembelajaran yang dapat digunakan adalah media pembelajaran berbasis komputer. Penelitian ini bertujuan untuk melihat efektivitas media pembelajaran mahasiswa terhadap sikap mahasiswa pada perkuliahan Geometri Ruang. Jenis penelitian adalah penelitian pengembangan. Penelitian ini akan mengembangkan media pembelajaran berbasis komputer pada mata kuliah geometri ruang. Model pengembangan yang digunakan dalam penelitian ini adalah model Instruksional Development Institute (IDI). IDI menerapkan prinsip-prinsip pendekatan sistem. Ada tiga tahapan pendekatan sistem, yaitu penemuan (define) atau analisis kebutuhan, pengembangan (develop), dan evaluasi (evaluate). Instrumen yang digunakan pada penelitian ini adalah angket sikap. Media pembelajaran berbasis komputer pada perkuliahan Geometri Ruang memunculkan sikap positif terhadap mahasiswa. Hal ini terlihat dari hasil angket sikap mahasiswa terhadap media pembelajaran berbasis komputer diperoleh keterangan bahwa sikap mahasiswa tertarik dan sangat tertarik terhadap media pembelajaran berbasis komputer. Hal ini tergambar dari hasil persentase yang diperoleh berkisar antara 66\%- 89\%. Berdasarkan penjelasan sebelumnya dapat disimpulkan penggunaan media pembelajaran berbasis komputer memberikan pengaruh yang positif sehingga dapat dijadikan sebagai media pembelajaran
\end{abstract}


pada perkuliahan Geometri Ruang.

\section{Keywords:}

Instructional

Learning,

Computer,

Attitude,

Geometry of Space

\section{PENDAHULUAN}

Kejenuhan mahasiswa terhadap penggunaan sumber belajar yang tidak bervariasi mengakibatkan motivasi belajar mahasiswa rendah. Hal ini juga berpengaruh pada hasil belajar mahasiswa pada perkuliahan Geometri Ruang. Berikut data hasil belajar mahasiswa Program Studi Pendidikan Matematika STKIP PGRI Sumatera Barat.

Hal tersebut diakibatkan oleh Materi perkuliahan Geometri Ruang bersifat abstrak sehingga Perkuliahan tanpa dibantu dengan media pembelajaran tentunya dapat menyulitkan mahasiswa dalam memvisualisasikan konsep-konsep yang bersifat abstrak tersebut. Oleh karena itu, perlu media pembelajaran yang mampu mengkonkritkan konsep-konsep dari materi Geometri Ruang.

Salah satu media pembelajaran yang dapat digunakan untuk mengatasi permasalahan di atas adalah media pembelajaran berbasis komputer. Penggunaan komputer dalam pembelajaran mandiri bukan barang baru tetapi merupakan salah satu inovasi teknologi pendidikan dalam pengembangan media pembelajaran yang dapat diandalkan. 
Media pembelajaran berbasis komputer adalah salah satu inovasi dari pembelajaran yang dapat digunakan untuk membantu memecahkan beberapa permasalahan yang dihadapi dalam perkuliahan Geometri Ruang. Media Pembelajaran Berbasis Komputer ini bisa dijalankan di CDROM pada komputer dengan spesifikasi minimal. Dalam Media Pembelajaran Berbasis Komputer ini disajikan materi perkuliahan yang harus dipelajari oleh mahasiswa dalam bentuk yang berbeda. Media Pembelajaran Berbasis Komputer ini dilengkapi dengan gambar-gambar, suara, serta gambar yang bergerak atau animasi yang dapat menarik dan memudahkan minat mahasiswa untuk belajar.

Berdasarkan latar belakang masalah di atas, peneliti tertarik untuk melakukan penelitian dengan judul Pengembangan Media Pembelajaran Berbasis Komputer pada Perkuliahan Geometri Ruang Di STKIP PGRI Sumatera Barat.

\section{METODE PENELITIAN}

Tabel 1. Kriteria Skala Sikap

\begin{tabular}{cl}
\hline Skor $(\%)$ & \multicolumn{1}{c}{ Kriteria } \\
\hline S $>80$ & Sangat tertarik \\
$60 \leq S<80$ & Tertarik \\
$40 \leq S<60$ & Cukup tertarik \\
$20 \leq S<40$ & Kurang tertarik \\
$S<20$ & Tidak tertarik
\end{tabular}

\section{HASIL DAN PEMBAHASAN}

Data sikap mahasiswa terhadap penggunaan media pembelajaran berbasis komputer diperoleh dari angket. Angket ini terdiri dari 24 pernyataan
Jenis penelitian ini adalah penelitian pengembangan. Penelitian ini akan mengembangkan media pembelajaran berbasis komputer pada mata kuliah geometri ruang. Model pengembangan yang digunakan dalam penelitian ini adalah model Instruksional Development Institute (IDI).

Instrumen penelitian ini adalah angket. Angket ini digunakan untuk mengukur sikap mahasiswa terhadap media pembelajaran berbasis komputer. Angket diberikan pada akhir perkuliahan menggunakan media pembelajaran berbasis komputer.

Untuk mengukur sikap mahasiswa terhadap perkuliahan menggunakan media pembelajaran berbasis komputer digunakan angket tertutup yang dianalisa dengan menggunakan skala likert.Penilaian skala sikap mahasiswa terhadap perkuliahan Geometri Ruang dengan menggunakan media pembelajaran berbasis komputer dengan kriteria pada Tabel 1.

Tabel 2. Indikator yang diamati pada Angket Sikap

\begin{tabular}{ll}
\hline No. & \multicolumn{1}{c}{ Indikator } \\
\hline 1. & Ketekunan \\
2. & Kerajinan \\
3. & Kepedulian \\
4. & Kedisiplinan \\
5. & Kerjasama \\
6. & Tanggung jawab \\
\hline
\end{tabular}

yang diberikan pada 21 orang responden. Pernyataan- pernyataan yang ada pada angket memuat pernyataan yang bertujuan untuk mengetahui bagaimana sikap mahasiswa dalam mengikuti perkuliahan dengan 
menggunakan media pembelajaran berbasis komputer. Ada 6 indikator yang termuat dalam pernyataan angket ini yang dapat dilihat pada Tabel 2 .

Untuk mengetahui sikap mahasiswa, indikator ketekunan dalam perkuliahan diwakili oleh pernyataan nomor $1,4,12$ sebagai pernyataan positif dan 6 sebagai pernyaataan negatif. Sedangkan indikator kerajinan diwakili oleh pernyataan nomor 2, 8, 14 sebagai pernyataan positif dan 19 sebagai pernyaataan negatif. Untuk indikator kepedulian diwakili oleh pernyataan nomor 15,20 sebagai pernyataan positif dan 21, 24 sebagai pernyaataan negatif . Untuk indikator kedisiplinan diwakili oleh pernyataan nomor 9,18 sebagai pernyataan positif dan 5,17 . Untuk indikator kerjasama diwakili oleh pernyataan nomor 16, 22 sebagai pernyataan positif dan 13, 23. Dan terakhir indikator tanggung jawab diwakili oleh pernyataan nomor 7,10 sebagai pernyataan positif dan 3,11 .

Berdasarkan hasil angket sikap mahasiswa terhadap media pembelajaran berbasis komputer diperoleh keterangan bahwa sikap mahasiswa tertarik dan sangat tertarik terhadap media pembelajaran berbasis komputer. Hal ini tergambar dari hasil persentase yang diperoleh berkisar antara 66\%- 89\%.

Secara keseluruhan untuk indikator ketekunan mahasiswa memperlihatkan sikap positif terhadap penggunaan media pembelajaran berbasis komputer. Hal ini tergambar dari persentase yang diperoleh untuk semua pernyataan yang mengandung indikator ketekunan memperoleh persentase untuk masingmasing pernyataan berturut-turut adalah $74 \%, 85 \%, 64 \%$ dan $69 \%$ lebih besar dari $60 \%$ artinya mahasiswa tertarik menggunakan media tersebut dalam perkuliahan mengakibatkan mereka tekun dalam belajar. Hal ini menggambarkan bahwa mahasiswa tidak mau meninggalkan perkuliahan dan merasa rugi jika meninggalkan pelajaran, apabila mereka menemukan kesulitan, mereka tidak berusaha untuk bertanya atau mencari jawaban tentang hal-hal yang tidak mereka pahami.

Indikator kerajinan mahasiswa juga memperlihatkan sikap positif terhadap penggunaan media pembelajaran berbasis komputer. Hal ini tergambar dari persentase yang diperoleh untuk semua pernyataan yang mengandung indikator kerajinan memperoleh persentase untuk masing-masing pernyataan berturut-turut adalah $76 \%$, $80 \%, 87 \%$ dan $99 \%$ lebih besar dari $60 \%$ artinya mahasiswa tertarik menggunakan media tersebut dalam perkuliahan mengakibatkan mereka rajin dalam belajar. Hal ini menggambarkan bahwa mahasiswa selalu mengulang pelajaran di rumah dan tidak menunda-nunda untuk mengerjakan tugas.

Indikator kepedulian mahasiswa juga memperlihatkan hasil yang sama dengan indikator lainnya yaitu menunjukan sikap positif terhadap penggunaan media pembelajaran berbasis komputer. Hal ini tergambar dari persentase yang diperoleh untuk semua pernyataan yang mengandung indikator kepedulian memperoleh persentase untuk masing-masing pernyataan berturut-turut adalah $66 \%$, $73 \%, 63 \%$ dan $66 \%$ lebih besar dari $60 \%$ artinya mahasiswa tertarik menggunakan media tersebut dalam perkuliahan mengakibatkan mereka peduli terhadap perkuliahan Geometri Ruang. Hal ini menggambarkan bahwa mahasiswa berusaha mengerjakan tugas-tugas yang ada pada media pembelajaran berbasisi komputer dengan sebaik-baiknya dan tidak merasa terpaksa dalam mengikuti perkuliahan karena banyak pengetahuan yang mereka dapat.

Indikator kedisiplinan mahasiswa juga memperlihatkan hasil yang sama 
dengan indikator lainnya yaitu menunjukan sikap positif terhadap penggunaan media pembelajaran berbasis komputer. Hal ini tergambar dari persentase yang diperoleh untuk semua pernyataan yang mengandung indikator kedisiplinan memperoleh persentase untuk masing-masing pernyataan berturut-turut adalah $85 \%$, $73 \%, 75 \%$ dan $69 \%$ lebih besar dari $60 \%$ artinya mahasiswa tertarik menggunakan media tersebut dalam perkuliahan. Hal ini menggambarkan bahwa mahasiswa disiplin dalam mengikuti perkuliahan.

Indikator kerjasama mahasiswa juga memperlihatkan hasil yang sama dengan indikator lainnya yaitu menunjukan sikap positif terhadap penggunaan media pembelajaran berbasis komputer. Hal ini tergambar dari persentase yang diperoleh untuk semua pernyataan yang mengandung indikator kerjasama memperoleh persentase untuk masingmasing pernyataan berturut-turut adalah $81 \%, 65 \%, 70 \%$ dan $69 \%$ lebih besar dari $60 \%$ artinya mahasiswa tertarik menggunakan media tersebut dalam perkuliahan. Hal ini menggambarkan bahwa mahasiswa mau memberikan bantuan kepada teman-teman yang lain yang mengalami kesulitan.

Indikator tanggung jawab mahasiswa juga memperlihatkan hasil yang sama dengan indikator lainnya yaitu menunjukan sikap positif terhadap penggunaan media pembelajaran berbasis komputer. Hal ini tergambar dari persentase yang diperoleh untuk semua pernyataan yang mengandung indikator tanggung jawab memperoleh persentase untuk masing-masing pernyataan berturut-turut adalah $83 \%$, $62 \%, 77 \%$ dan $62 \%$ lebih besar dari $60 \%$ artinya mahasiswa tertarik menggunakan media tersebut dalam perkuliahan. Hal ini menggambarkan bahwa mahasiswa bersungguh-sungguh dalam belajar.

\section{KESIMPULAN}

Media Pembelajaran Berbasis Komputer merupakan bahan perkuliahan mahasiswa Program Studi Pendidikan Matematika STKIP PGRI Sumatera Barat yang dapat digunakan untuk perkuliahan Geometri Ruang. Media Pembelajaran Berbasis Komputer dirancang dengan menggunakan macromedia flash. Media ini disajikan dalam bentuk persentasi terdiri dari 3 pertemuan yang membahas materi tentang jarak pada bangun ruang.

Media ini dikembangkan melalui tiga tahap yaitu penemuan (define) atau analisis kebutuhan, pengembangan (develop), dan evaluasi (evaluate). Berdasarkan hasil penelitian, diperoleh kesimpulan bahwa Media Pembelajaran Berbasis Komputer pada perkuliahan Geometri Ruang sudah efektif berdasarkan sikap mahasiswa pada perkuliahan geometri ruang.

Hasil penelitian ini menunjukkan bahwa perkuliahan dengan menggunakan Media Pembelajaran Berbasis Komputer pada perkuliahan Geometri Ruang yang dikembangkan pada penelitian ini dapat menimbulkan sikap positif. Oleh karena itu Media Pembelajaran Berbasis Komputer pada perkuliahan Geometri Ruang dapat dijadikan salah satu alternatif bahan perkuliahan bagi Dosen dan mahasiswa.

Media Pembelajaran Berbasis Komputer pada perkuliahan Geometri Ruang ini dapat dijadikan contoh bagi Dosen dalam mengembangkan Media Pembelajaran Berbasis Komputer pada perkuliahan Geometri Ruang yang lain. Perbaikan dan modifikasi dapat dilakukan dengan tetap memperhatikan langkah-langkah pada penyusunan Media Pembelajaran Berbasis Komputer pada perkuliahan Geometri Ruang. 


\section{UCAPAN TERIMA KASIH}

Terbitnya tulisan ini tidak terlepas dari bantuan berbagai pihak, untuk itu penulis ucapkan terima kasih yang sebesar-basarnya kepada Pihak STKIP PGRI Sumatera Barat khususnya pengelola jurnal Pelangi yang telah memberikan kesempatan kepada penulis untuk menulis dijurnal Pelangi. Selanjutnya penulis juga berterima kasih kepada para penyumbang sumber insirasi yang telah memerikan inspirasi bagi penulis untuk mengutip atau menggunakan tulisannya sebagai bahan referensi.

\section{DAFTAR RUJUKAN}

Amdal, Yusri. 2008. "Pengaruh Metode Penemuan Terbimbing terhadap Hasil Belajar Matematika pada Pokok Bahasan Bangun Ruang Sisi Lengkung Siswa Kelas IX di MTsN I Bukittinggi Tahun Pelajaran 2007/2008". Tesis tidak diterbitkan. Padang: PPS UNP.

Ansyar dan Sembiring. 2001. Hakikat Pembelajaran MIPA dan Kiat Pembelajaran Matematika di Perguruan Tinggi. Jakarta: PAUPPAI Universitas Terbuka

Arsyad, Azhar. 2011. Media Pembelajaran. Jakarta: Rajawali Press.

Bloom, Benjamin S,dkk. 1964. Taxonomy of Educational Objectives. Amerika: Longmans

Crider, Andrew B. 1983. Psychology. USA: Scortt Foresman and Company.

Dimyati dan Mudjiono. 2006. Belajar dan Pembelajaran. Jakarta: PT Rineka Cipta.
Dina Mustafa. 2001. Memotivasi Mahasiswa untuk Kuliah dan Belajar Sepanjang Hayat. Jakarta: PAU-PPAI Universitas Terbuka.

Hamdani. 2011. Strategi Belajar Mengajar. Bandung: CV Pustaka Setia.

Jensen, Eric. 1998. Teaching with the Brain in Mind. Virginia USA: Association for Supervision and Curriculum Development.

Keller, John M. 1983. Motivational Design of Instruction. Dalam Reigeluth, Charles M. (Ed.), Instructional Design Theories and Model: An Overview of their Current Status. London: Law Rence Erldaum Associates Publishers.

Mar'at. 1982. Sikap Manusia Perubahan Serta Pengukurannya. Bandung : Ghalia Indonesia

Muliyardi. 2002. Strategi Belajar Matematika. Padang: FMIPA.

Nana Sudjana dan Ahmad Rivai. 2003. Teknologi Pengajaran. Bandung: Sinar Baru Algensindo.

Pribadi, Benny A. 2010. Langkah Penting Merancang Kegiatan Pembelajaran yang Efektif dan Berkualitas Model Desain Sistem Pembelajaran. Jakarta: Dian Rakyat

Riduwan. 2005. Belajar Mudah Penelitian untuk Guru, Karyawan, dan Peneliti Pemula. Bandung: Alfabeta.

Setiawan dkk. 1997. Teknologi Pengajaran. Bandung : Sinar Baru Algesindo 
Suherman, Erman dkk. 2003. Common TextBook Strategi Pembelajaran Matematika Komtemporer. Bandung: JICA-Universitas Pendidikan Indonesia (UPI)

Trianto. 2007. Model Pembelajaran Terpadu dalam Teori dan Praktek. Jakarta: Prestasi Pustaka. 